\title{
The importance of relationships in the classroom
}

\author{
Annika Lilja \& Silwa Claesson
}

\section{Silence is golden?}

Swedish politicians and media have claimed that a classroom with order and discipline is a silent classroom, where each pupil works on their own tasks. These demands have been answered with claims that it is possible to achieve discipline in the classroom in a different way, and that what has been called a more holistic view on teaching and learning is needed. This essay seeks answers about what kind of solutions have been used earlier in history, but with the main focus on today's teaching when it comes to classroom discipline. Whether the pupils are interested in learning what is planned for the lesson or not, the teacher has the responsibility of keeping the classroom under control. What we mean by a lesson where there is order and discipline is not necessarily that all pupils work quietly on their own, but that the teacher and the pupils are directed towards the same object and that the pupils have the opportunity to expand their horizons, although there might, on and off, be a bit of hustle and bustle in the classroom. Even though the examples from four different classrooms described in this essay differ when it comes to subjects and the pupils' age, we have searched for and discovered some teaching patterns that go beyond these factors. This study is a contribution to an ongoing discussion in the field of Allgemeine Didaktik or general didactics. 
In a study about order and discipline in the classroom it is useful to look at the historical background to the discussion of today's order and discipline in the classroom. When attendance at school became mandatory in Sweden in 1842, the so-called Lancaster model was recommended (Landahl 2011). This English model was based on Bell and Lancaster's principles of teaching, where up to 900 pupils were taught at the same time by one teacher. The pupils stood in groups under the guidance of an older or a particularly skilled pupil known as a monitor. The teachers were available in the classroom, but they were mainly silent. For different types of offences there were punishments-for example, the pupils were not allowed to be quiet. The sound was therefore mostly cacophonous (Larsson \& Westberg 2014). During the late nineteenth century, several people, such as cultural figures and politicians, opposed the Lancaster system. In Sweden, a so-called 'Normal Plan' was introduced for the school, which meant that the classes were not as big as before, pupils were to sit on chairs with a bench in front of them. The pupils were now seated, facing their teacher, so it would be possible for the teacher to control them, and when the pupils wanted to talk they were supposed to raise their hands. Corporal punishment was applied at the teacher's discretion, and the Normal Plan also introduced homework. Landahl (2011) emphasizes that this was a new way to organise teaching-now the teachers spoke and moved around the room, not the pupils. In the late nineteenth and early twentieth centuries, many ideas about how schools could function in alternative ways were presented. Reforming educators such as John Dewey (1959), Rudolf Steiner (Nobel 1991), Maria Montessori (1967), and Ellen Key (Ambjörnsson 2013) published texts about learning environments that were based on humanist values, and they showed how teaching could be arranged so that every individual pupil could develop and learn in a more personal way. However, these famous educators who advocated new ways of teaching initially met with little interest in the Swedish community (Hartman 2005).

Order and discipline in school is a topic that has engaged both politicians and the public (Utbildningsdepartementet 2010). This 
means that whether teachers will succeed in maintaining discipline in the classroom is a constant concern to many social actors, and is of interest to almost everyone. However, as children's roles in society have changed, it seems reasonable to assume that the methods for accomplishing a good classroom climate also need to change (Wedin 2007).

We have looked at two different ways of viewing teachers' work with order in the classroom. The first perspective stresses how different methods affect pupils' behaviour in the classroom by using the key concept 'classroom management' (for example, Lewis et al. 2014; Montuoro \& Lewis 2014; Simonsen et al. 2008). 'Classroom management' is generally speaking about strategies that help teachers to make lessons work as well as possible by responding to different actions of pupils in the classroom. The most common strategies are related to pupils' behaviour (Montuoro \& Lewis 2014). The main line in classroom management is to prevent pupils from disturbing the teaching (Simonsen et al. 2008). The strategies that teachers are expected to use are often designed on a general level, and originate from evidence-based practice (Levinsson 2013). The purpose of these strategies is to allow teachers to deal with pupils successfully and to improve pupils' behaviour (Lewis et al. 2014).

The second perspective takes a relational approach to education. Relational pedagogy is often associated with philosophers such as Martin Buber (1990) and Otto Bollnow (1989). Both Buber and Bollnow are interested in how relations between people can be expressed. Buber (1990) proposed a third way for pedagogy, not an individualistic or collective one, but an interpersonal way, where the learning occurs in the gap between two people. Bollnow (1989) highlighted the importance of the teacher's belief in his or her pupils and therefore that the teacher's trust in the pupils should be a starting point, because children are shaped by the expectations they experience. If the teacher expects that the pupil is going to behave badly, it may mean that this is exactly what the pupil will do. Today, many researchers address the importance of relations for the quality of teaching and for pupils' ability to learn (for example, Biesta 2004 \& 2009; Bingham \& Sidorkin 2004). Biesta (2004) argues that 
education is not what the teacher says and does, nor is it the pupils' activities, but the interaction between the two-a theory of education is a theory about relationships. In Sweden, classroom studies have also been conducted that in various ways highlight the relationship between teacher and pupils (for example Aspelin 2015; Rinne 2015; Levinsson 2013; Lilja 2013a; Frelin 2010, 2012; Aspelin \& Persson 2011; Claesson 2011). The main focus in all these studies is not discipline in school, but something they have in common is that they highlight a different role for today's pupils and what consequences this might have in various classroom contexts. Further, these studies show how a new role for the pupils has changed the role of the teacher. A teacher needs to earn the pupils' trust, interest and attention in a different way from fifty years ago (Bingham 2004), which implies that discipline in today's schools is maintained in a new way, where the relational aspects of teaching and learning are taken into account. This means that order and discipline in the classroom, from a relational perspective, is intertwined with the teaching.

\section{Theory and method}

The ways of viewing order in the classroom are changing. To investigate the effects of this, we have returned to our earlier studies, but now with a view to analysing how teachers maintain discipline in Swedish classrooms of today. The observations (Lilja 2013; Claesson 2011; Claesson 2005) were carried out with the purpose of capturing the relationships between teaching and learning and the relationships between teacher and pupils. To create an understanding, we have used a phenomenological-hermeneutic theory (for example, Lilja 2015; Bengtsson 2013; Lilja 2013; Claesson 2011; Claesson 2009; Berndtsson et al. 2007; Claesson 2004; Van Manen 1991; Van Manen 1991). In using a phenomenological approach, there is an ambition to intertwine life and world, and a central idea in this approach is that everyone is always directed towards something, which implies that this is an important component when teaching as well (Claesson 2008). A study in this tradition implies that the phenomenon-in this essay order and discipline-is presented in 
a broad and rich way. Van Manen (1991) uses the term 'tact' to describe the subtle and ethical nuances that are implied in teachers' daily life with their pupils: teachers have to be tactful in relation to their pupils. However, it is primarily the concept of the horizon that is used in this study in order to discern how discipline appears in today's classroom. Husserl (1970) introduced this concept, and Gadamer (2005) has developed it, but here it is above all inspired by Merleau-Ponty (2008), who suggests that we experience the world in a non-dualistic way-where body and soul are regarded as intertwined. Each person has an implicit horizon, which means that different directions and perspectives emerge (Van Manen 1991) and the horizon changes continuously (Berndtsson 2001). The concept of horizon can be used in order to see 'what it is possible for us to achieve' (horizon of opportunity), and it can also be used as a horizon of action: everyone is aware of their opportunities and choices and chooses to act according to them (ibid.). In a classroom, all pupils experience what happens from their own unique perspective, which means that it is a challenge for the teacher to reach all of them and make them choose to act according to the purpose of the lesson, instead of choosing activities that may interfere with what the teacher has planned. Since we view order and discipline in a classroom as a situation when teacher and pupils are directed towards the same object, we use the concept horizon in the field of didactics to elicit knowledge about how teachers assist their pupils to expand their horizons during a given lesson.

This essay is based on observations in various classrooms. All three studies, with four teachers in the first, six teachers in the second and five teachers in the third, constitute the basis for the results. The studies have been previously reported in part (Lilja 2015; Lilja 2013a; Lilja 2013b; Lilja 2011; Claesson 2008; Claesson 2005; Claesson 2002; Claesson 1999) and the empirical material has now been used again because it is a rich source where a detailed picture of the everyday classroom emerges. The material that is used in this essay does not contradict the material that was not selected. Rather than interpreting all the relevant situations, we have chosen to cite only data from a total of four teachers in this essay. The teachers were selected 
because each represents one of the teaching strategies found in the material, and because they are working both in compulsory school and in upper-secondary school. All observations were carried out in a similar fashion, where the main focus was on the teacher and notes were taken for 250 days in total, with the notes transcribed and interpreted. This means that what we present here represents a long-term pattern of observations and in this essay we are able to give only a few examples. We switch between general and specific events. In terms of selection, in Claesson's studies the teachers, after answering a survey, applied to participate in the studies; in Lilja's study, schools in various socio-economic areas were contacted and the participating teachers were recommended by a headmaster or colleague.

According to Ricoeur (1988), the emancipation of the action from the acting person gives an independence that he compares to the semantic autonomy of the text. The action leaves a trace. The analysis started with the selection of situations that were interpreted as having to do with order and discipline. When it comes to capturing an action, Ricoeur (2009) suggests that the action can become an object of scientific study without losing importance, through a special kind of objectification. This implies that the action is a pattern that is described and interpreted according to its internal connections. Hermeneutics implies a constant contextualisation, in that there is a constant oscillation between the whole and the part. The selected situations were read several times and organised in different ways before the presented results appeared. The context has been crucial to our interpretations, but the parts have also been necessary for us to get a sense of the whole picture when it comes to order and discipline in various classrooms. After the analysis was complete, four situations were chosen for this essay.

\section{Results}

The teacher's authority is not self-evident just because he or she is a member of a profession with a fairly high status (Levinsson 2013; Lilja 2013a; Frelin 2010; Wedin 2007; Claesson 1999). However, our empirical material shows that teachers do not plan their lessons 
primarily with the thought of maintaining discipline. Rather, they plan to give their pupils opportunities to learn the intended content of the lesson. In the classroom studies presented here, we have nevertheless identified three different strategies for teaching that affect the teacher's ability to maintain discipline: individualisation, group instruction, and an oscillation between individual and group instruction.

\section{Individualising the teaching}

Adam is a science teacher at an upper-secondary school in an area with a large number of immigrants. Adam regards every pupil as unique, and should be met with unique questions from the teacher, which is his way to encourage pupils to search for knowledge independently. Adam has come to a conclusion that education in an environment such as his must be designed according to these ideas, and his teaching follows the same structure during every lesson and in all classes. For him, teaching boils down to the idea that every pupil should have the opportunity to ask the teacher questions that result from their own curiosity within the domain of science. This implies that the pupils cannot always study the same content at the same time. Adam tells the pupils to formulate a question of their own, and then asks them to describe in writing how they are going to get the answers to their own questions. Adam's idea about individualisation implies that every pupil should get to work with their personal issues in the school laboratory where they are expected to carry out various experiments.

In the classroom, Adam moves around assisting pupils one at a time, and the conversations he has with his pupils can be described as being of a Socratic nature or using open questions, which he himself hardly ever answers. His idea is that pupils should also take notes about what they are studying.

- I do not know what to write, one girl says.

- Can't you write what you learnt about plants and water? Adam asks.

- Why do we have to write so much? another pupil asks. 
- In order to know what you think about the topic, a third pupil answers.

- So you can see that we have developed, says a boy with a glance at Adam.

- Do $I$ have to know that? Adam responds.

In this situation, it appears that while one pupil does not know what to write, another wonders why they have to write so much. They try to get Adam to tell them what the point of writing is, but they don't really get a clear answer. Adam responds, as often is the case in the classroom context, with a new question.

From the observations in the classroom, it is clear that some pupils are passive.

- Honestly, I have not learnt anything at all, says a girl who seems restless.

She wants Adam to tell her how things are linked, but it is clear that Adam wants her to figure it out on her own.

The implications of this way of teaching are that many pupils have a unique opportunity to have Adam's support, but that many pupils are also left to their own devices, and far from everyone can find their own interesting question, or develop the question independently in the classroom environment. So instead, many pupils deal with other things that do not have any bearing on the aim of the lesson. Several pupils are chatting with each other while Adam has long conversations with one or sometimes two pupils at a time.

From a discipline perspective, although some pupils have a lot of support, many pupils seem to be left without guidance and with unanswered questions that seem to make them anxious and frustrated. Therefore, the pupils who are left behind may not have the opportunity to expand their horizons in such a way that they have opportunities to learn the intended content of the lesson. Instead of working with their assignments, they do other things. Some of them seem to think it is nice to decide for themselves what to do, and they chat about various things that interest them. Other pupils 
take advantage of the opportunity to get 'private tuition' from their teacher, and they seek Adam's attention and develop well in the subject. Adam continues with his way of teaching even though he does not reach all his pupils. To sum up, individualising teaching causes some problems. The largest problem from an order and discipline point of view is that too many pupils are left alone in the classroom, and this means that Adam loses many pupils' interest and attention. Most of all, he loses the pupils who do not understand what the teaching is about from the start. The working environment in the classroom, where many different activities are going on, is confused, and a good many activities have nothing to do with science.

\section{Working with the whole class}

If individualisation does not work, would it be better to teach the whole class at the same time? John is a history and civics teacher at an upper-secondary school. He is directed towards the whole class and gives lectures. John is also deeply engaged with his subjects and prepares each lesson carefully.

On one occasion, John gives the class a description of the historical background to the conflict between Jews and Muslims in Israel.

- It's 1914. What happened then?

- The First World War, a pupil answers.

- Yes.

John moves while he speaks. He walks back and forwards, looking at the pupils and talking with enthusiasm.

- And now they do a thing that is really momentous.

He describes how countries were formed and their borders set after the First World War.

- It was decided over all of their heads. 
John is completely engaged in the content and this is reflected in his body language. However, John is unsure how to deal with these classes because they are vocational training classes and they do not relate to the teaching in the same way as the classes he has been accustomed to teaching. Most of John's experience has been in a school where pupils brought paper, pens, and folders, wrote down what he said, and attended exams. Now things have changed and John has no alternative teaching strategies. Like Adam, John does not change his teaching when he notices that some of the pupils are not focused on the goal for the lesson. He works in the way that he worked before, and that is as far as his horizon reaches. So what he does is to prepare even more, but he prepares more of the same, and not all the pupils appreciate that. Some skip lessons; some do not listen at all. The pupils' and Johns' horizons do not meet in a joint goal for the lesson.

It seems this method of teaching, addressing all the pupils in the class at the same time, is not always successful either. This despite the fact that the method corresponds to the convention used in schools for over a century: pupils sit facing forward, silent, and listen to the teacher. In this case, by using just one teaching method, John loses his pupils; many of them are neither motivated nor interested - not in the subject and not in working. This means that the pupils do not expand their horizons when it comes to the subjects John teaches. Their horizons might even shrink when the pupils experience their education to be useless.

From a discipline perspective, neither the method of addressing the pupils as a group and only having sparse communication between teacher and pupil nor individualisation seem to work. When the pupils lose interest in what John says, they move their focus to other things that interest them more. Some of the pupils even go so far as to not attend lessons, as they consider something else to be more meaningful. Other pupils who are actually in the classroom deal with other concerns than the teacher intends. 


\section{Oscillating between the individual and the class}

Some of the teachers in our studies show an ability to have a relationship with the class, with small groups, and with individual pupils almost simultaneously. These teachers consider the relationship with the pupils to be a determining factor in successful teaching. An example of such a situation is when Susanna, who teaches pupils aged 7 and 8 , is going to read a story for her pupils.

The pupils are gathered in a circle on the floor and Susanna sits on a small chair. She is going to read a detective story and the pupils are supposed to figure out who is the thief in the story. Susanna begins to read with empathy: she uses her voice and she seeks eye contact with her pupils when she takes short pauses. Despite this, it does not take long before two of the pupils begin to talk to each other. They lose interest in the story and talk about something they regard as more important. This interferes with Susanna's reading and disturbs the other pupils who want to listen. Susanna interrupts her reading and asks them to be quiet. They oblige for a little while, but soon they start talking again. This time Susanna looks at them with stern eyes as she leans towards them and says to them with a firm voice. 'Now I want you to be silent.' When Susanna has reprimanded the two pupils, she reverts to her former posture and tone of voice, and continues to read with enthusiasm. However, two other pupils start to quarrel with each other. Max has a wooden bead on the floor in front of him and Carl grabs it, which Max does not like. Max, irritated, tries to take the bead back, but Carl refuses. Susanna interrupts her reading for the third time, gets up from her chair, takes three steps forward and takes the bead from Carl without saying anything. Susanna keeps the bead in her hand as she sits down again. She looks Max and Carl in the eye before she continues reading again with a friendly voice. A peaceful and quiet mood settles over the group. Now there is calm in the circle and Susanna finishes the story.

In this situation, the teacher has a plan for the lesson and has set an object for what she wants her pupils to learn. In order for the teacher and the pupils to be directed towards the same object, Susanna needs 
to have an individual relationship both with her pupils and with the whole class. However, it turns out that some of the pupils do not have the same goal for the lesson as the teacher and they start to talk and argue with each other. In this way, they disrupt both Susanna's reading and the group's opportunities to learn the intended content. To resolve the situation so that the lesson can continue undisturbed, Susanna needs to deal with what is happening in such a way that all the pupils are directed towards the same goal. The consequence of Susanna's teaching, where she oscillates between those who need extra attention and the whole class, is that it finally makes the pupils do what she has planned. From a disciplinary perspective, Susanna handles the situation by rebuking the pupils who disrupt the lesson. The other pupils who want to listen to the detective story are met with empathy and commitment. In this way, she resolves the difficulties together with the children, who for a moment are caught up in issues other than the detective story. Susanna's pupils have the opportunity to expand their horizons in terms of the lesson content.

Another example of oscillation between the individual and the group is a lesson in biology with Peter, who is a teacher of Year 9 pupils who are going to do a test. Jeanette is often absent from the lessons, but today she is in the classroom. However, she does not have enough knowledge to answer the questions in the test, and so Peter lets her do it with support from her biology book. Jeanette finishes her test quite quickly and gives it back. Then she leans back against the wall and puts her feet on the chair next to her, puts in her earphones, and starts to paint her fingernails. While the other pupils are still deeply absorbed in their tests, a sharp smell of nail polish spreads through the classroom. No one seems to react-neither the teacher nor the rest of the pupils.

In a conversation after the lesson, Peter is asked if pupils are allowed to do a test with support from the book, and to paint their nails during the lesson. Yes, he says, but only Jeanette, who is a special pupil and needs special conditions. School is not particularly important for her and if she is put under pressure, she leaves the classroom. Peter's task as a teacher is to give all pupils the opportunity to succeed based on their individual abilities, which means that Jeanette has her own rules. 
The consequence of Peter's teaching ideas is that he strives to make it possible for his pupils to find their own horizons of opportunity, and then choose to act and thereby extend their knowledge in the subjects Peter teaches. Because Jeanette feels trusted and is given rules that she can accept, she chooses to attend Peter's lessons to a greater extent than she does others. Peter can, to some extent, push her to work, and because of that she does not disturb the others by talking and disrupting the lessons. Peter meets her needs, and Jeanette respects the limits Peter sets up for her. The other pupils accept Jeanette's special conditions, as Peter treats all his pupils as though they have equal value. Many of them want to perform well in order to get high grades and advance in the education system, and he gives them what they need: interesting teaching and an expectation that they are capable of doing well. The pupils appear in different ways to the teacher, and Peter also responds to them in different ways depending on who they are. From a disciplinary perspective, this implies that the mutual trust that Peter and his pupils have for each other means that the pupils want to make an effort to do a good job.

Susanna and Peter thus change their ways of teaching when they notice that they have lost some of their pupils' attention during the lesson. Their oscillation between individual pupils and the entire group contributes to the pupils and the teacher being directed towards the same object, and in that way the pupils' horizons expand. The oscillation also contributes to the pupils seeing their opportunities to learn, and the mutual trust between teacher and pupils means that the pupils choose to do the work needed for them to learn. When teachers can talk to the class as a whole and at the same time meet their pupils' different needs, this benefits individual pupils, different groups in the class, and the class as a whole.

\section{Discussion}

Dealing with pupils who disturb order in the classroom and pupils' lack of motivation is a part of the teacher's practice, and it is an aspect of a teacher's work that is often discussed among politicians and in the press. These discussions tend to highlight problems with discipline 
as a reason for pupils' declining results in national and international tests, and both politicians and the public have suggestions about how discipline could be improved. Often you will hear that things were better in the past. But what do we mean by 'the past' and what was better? Does this mean the Lancaster era when the teacher was supposed to be quiet? Or is it the reactions to this method, when the pupils were supposed to put up their hands if they wanted to say something and could be punished physically if they did not behave? Or is it perhaps the humanist values, such as those advocated by John Dewey and Ellen Key? A look back in history shows that the view on what order in a classroom means has changed. That pupils need to be disciplined in some way is a fact that was valid a hundred years ago as well as today, but with regard to the question of how it can be achieved, there are several answers. This essay focuses on a present-day perspective, the relational perspective. Of the fifteen teachers who participated in our studies, four of whom we have discussed in this essay, we see that the teachers who have the ability to oscillate between seeing the individual pupil and meeting the needs of the whole class are the teachers who are most successful both in terms of order and discipline in the classroom, and also when it comes to giving the pupils opportunities to learn the content of the lesson.

By using the phenomenological and hermeneutical concept of the horizon (Husserl 1970; Merleau-Ponty 2008; Berndtsson 2001), we have been able to show how differences between teachers' strategies - the teachers' horizons, for example-affect the pupils' opportunities to expand their horizons when it comes to the intended content of different lessons. Adam was a teacher whose mind was clear when it came to teaching, and his teaching can be compared to the pedagogical humanist values described above. His horizon was stuck at one, and only one, basic idea of learning and teaching. Adam's method gave only a few pupils the opportunity to expand their horizons. The result was that many pupils did not realise what their opportunities to learn really were.

John's teaching horizon was also fixed. He had only one way to teach and that was to give lectures. His ideas might be influenced by behaviourism in the sense that he did not regard the pupils as 
individuals, but perhaps more as a bowl to be filled with knowledge. His teaching methods can in some ways also be compared with the Swedish Normal Plan, introduced by Rudenschöld in the nineteenth century, in that not all pupils had the opportunity to broaden their horizons or to choose the activity needed in order to learn more history. Most of John's pupils chose an activity that neither encouraged learning nor order in the classroom.

These two ways of teaching differ from Susanna's and Peter's methods, and they also differ from the three historical ways of teaching described in this essay, since for Susanna and Peter, learning happens in the gap between the teacher and the pupils (Biesta 2009). Through the interaction with the pupils, and through an oscillation between the individual and the group, Susanna and Peter manage to engage their pupils in such a way that the pupils give themselves the opportunities to expand their horizons.

Bollnow (1989) considers a teacher's belief in the pupils to be crucial when it comes to how they succeed in school. The pupils need a teacher who sees their capabilities and expands their horizons, and who dares to act without being afraid to fail, according to both Bollnow (1989) and Buber (1990). By comparison, the 'classroom management' approach, where detailed strategies are common features (Lewis et al. 2014), risks viewing pupils as objects: as all pupils are treated in the same way regardless of the reason for pupils' disruptive behaviour and regardless of pupil needs. This method can be perceived as both overly theoretical and bureaucratic. The mission of the school is to educate children and young people, and when pupils do not want to be educated as planned, it is still the teacher's assignment to persevere. The didactical knowledge of our study is that to achieve this, at least in a Swedish school context, an ability is required of the teacher to build relationships with pupils and to teach with the individual pupils' needs and the group's best interests simultaneously in view. The didactical consequence of this essay is that order and discipline is embedded in teaching activities. Where teachers in the past had to be flexible in both content and methods, teachers today need to be all that, i.e. flexible in content and methods and flexible towards their pupils too. 


\section{References}

Ambjörnsson, R. (2013), Ellen Key: En europeisk intellektuell (Stockholm: Bonnier).

Aspelin, J. \& S. Persson (2011), Om relationell pedagogik (Malmö: Gleerups). - - (2015), Inga prestationer utan relationer (Malmö: Gleerups).

Bengtsson, J. (2013), 'With the lifeworld as ground: A research approach for empirical research in education: The Gothenburg tradition', Indopacific Journal of Phenomenology, special issue, 13, 1-18.

Berndtsson, I. (2001), Förskjutna horisonter: Livsförändring och lärande $i$ samband med synnedsättning. (diss., Studies in Educational Sciences, 159 (Gothenburg: Acta Universitatis Gothoburgensis).

- - S. Claesson, F. Friberg \& J. Öhlén (2007), 'Issues about thinking phenomenologically while doing phenomenology', Journal of Phenomenological Psychology, 38, 256-77.

Biesta, G. (2009), 'Good education in an age of measurement: On the need to reconnect with the question of purpose in education', Educational Assessment, Evaluation \& Accountability, 21/1, 33-46.

Biesta, G. (2004), 'Mind the Gap! Communication and the Educational Relation', in C. Bingham \& A. M. Sidorkin (eds.), No Education without Relation (New York: Peter Lang).

Bingham, C. (2004), 'Let's treat authority relationally', in C. Bingham \& A.M. Sidorkin (eds.), No Education without Relation (s. 23-38) (New York: Peter Lang).

_- \& A. M. Sidorkin (2004), No Education without Relation (New York: Peter Lang).

Bollnow, O. F. (1989), 'The Pedagogical Atmosphere', Phenomenology + Pedagogy, 7, 5-63.

Buber. M. (1990), Det mellanmänskliga (Ludvika: Dualis).

Claesson, S. (1999), 'Hur tänker du då?' Empiriska studier om relationen mellan forskning om elevuppfattningar och lärares undervisning, Göteborg Studies in Educational Sciences 130 (Gothenburg: Acta Universitatis Gothoburgensis).

- - (2002), Spår av teorier i praktiken (Lund: Studentlitteratur).

- - (2004), Lärares Levda kunskap, Göteborg Studies in Educational Sciences, 217 (Gothenburg: Acta Universitatis Gothoburgensis).

- - (2008), 'Life-world phenomenology and empirical studies', Nordisk Pedagogik, 2-4, 123-34.

_- (2011), Lärares hållning (Lund: Studentlitteratur).

Dewey, J. (1959). Democracy and education an introduction to the philosophy of education (Text-book series). New York.

Frelin, A. (2012), Lyhörda lärare: Professionellt relationsbyggande i förskola och skola (Stockholm: Liber). 
Frelin, A. (2010), Teachers' Relational Practices and Professionality (diss., Uppsala: Institutionen för didaktik, Uppsala universitet).

Gadamer, H. G. (2005), Truth and Method (London: Continuum).

Hartman, S. (2005), Det pedagogiska kulturarvet: Traditioner och idéer i svensk undervisningshistoria (Stockholm: Natur och Kultur).

Husserl, E. (1970), The Crisis of European Sciences and Transcendental Phenomenology (Evanston: Northwestern University Press).

Landahl, J. (2011), 'Ljudet av auktoritet: Den tysta skolans uppgång och fall', Scandia, $77 / 1$.

Larsson, E. \& J. Westberg (2011) (eds.), Utbildningshistoria (Lund: Studentlitteratur).

Levinsson, M. (2013), Evidens och Existens: Evidensbaserad undervisning i ljuset av lärares erfarenheter (diss., Gothenburg Studies in Educational Science, 339; Gothenburg: Acta Universitatis Gothoburgensis).

Lewis, T. L. Mitchell, B. S. Trussell, R. \& Newcomer, L. (2014), 'School-Wide Positive Behavior', in E. T. Emmer \& E. J. Sabornie (eds.), Handbook of Classroom Management (Abingdon: Routledge).

Lilja, A. (2011), 'Arbetsallianser i klassrummet', in S. Claesson (ed.), Undervisning och existens (Gothenburg: Daidalos).

- - (2013a), Förtroendefulla relationer mellan lärare och elev (diss., Gothenburg Studies in Educational Science, 338 (Gothenburg: Acta Universitatis Gothoburgensis).

_- (2013b), 'Body, Space and Time-And their influences on trustful relations in the classroom', Indo-pacific Journal of Phenomenology, special issue 13, 1-10. _- (2015), 'Hur lärande kan möjliggöras och hindras i skolan', in J. Bengtsson \& I. C. Berndtsson (eds.), Lärande ur ett livsvärldsperspektiv (Malmö: Gleerups). Merleau-Ponty, M. (2008), Phenomenology of Perception (London: Routledge) (first pub. 1962).

Montessori, M. (1976), Barndomens gåta (Jönköping: Seminarium).

Montuoro, P. \& Lewis, R. (2014), 'Student Perceptions of Misbehavior and Classroom Management', in E. T. Emmer \& E. J. Sabornie (eds.), Handbook of Classroom Management (Abingdon: Routledge).

Nobel, A. (1991), Filosofens knapp (Stockholm: Carlsson).

Pedersen, J. (2004), Vägar till värderingar och värden: Skolans sociala fostran $i$ läroplanstexter och pedagogisk praktik (Linköping: Institutionen för beteendevetenskap, Linköpings universitet).

Ricoeur, P. (2009), Hermeneutics and the Human Sciences (Cambridge: CUP) (first pub. 1981).

Ricoeur, P. (1988), Från text till handling: En antologi om hermeneutik (Lund: Symposion).

Rinne, I. (2015), Pedagogisk takt i betygssamtal: En fenomenologisk hermeneutisk studie av gymnasielärares och elevers förståelse av betyg, diss., Gothenburg 
Studies in Educational Science, 364 (Gothenburg: Acta Universitatis Gothoburgensis).

SAOL (2018), Svenska Akadamiens ordlista, http://svenska.se/saol/.

Simonsen, B., Fairbanks, S., Briesch, A., Myers, D. \& Sugai, G. (2008), 'Evidence-based Practices in Classroom Management: Considerations for Research to Practice', Education \& Treatment of Children, 31/3, 351-80.

Utbildningsdepartementet (Ministry of Education and Research) (2010), Skollagen 2010:800.

van Manen, M. (1991), The Tact of Teaching (Alberta: Faculty of Education, University of Alberta).

- - (1997). Researching lived experience: Human science for an action sensitive pedagogy (2.nd ed.). Ontario: Althouse press.

Wedin, A.-S. (2007), Lärares arbete och kunskapsbildning. Utmaningar och inviter i den vardagliga praktiken, diss., Linköping Studies in Pedagogic Practices, 2; Linköping Studies in education and psychology, 113 (Linköping: Institutionen för beteendevetenskap och lärande, Linköpings universitet). 